American University Washington College of Law

Digital Commons @ American University Washington College of

Law

Articles in Law Reviews \& Other Academic

Journals

Scholarship \& Research

2010

\title{
Empirical Modalities: Lessons for the Future of International Investment
}

Susan Franck

American University Washington College of Law, sfranck@wcl.american.edu

Follow this and additional works at: https://digitalcommons.wcl.american.edu/facsch_lawrev

Part of the Banking and Finance Law Commons, International Law Commons, and the Law and Economics Commons

\section{Recommended Citation}

Franck, Susan, "Empirical Modalities: Lessons for the Future of International Investment" (2010). Articles in Law Reviews \& Other Academic Journals. 1374.

https://digitalcommons.wcl.american.edu/facsch_lawrev/1374

This Article is brought to you for free and open access by the Scholarship \& Research at Digital Commons @ American University Washington College of Law. It has been accepted for inclusion in Articles in Law Reviews \& Other Academic Journals by an authorized administrator of Digital Commons @ American University Washington College of Law. For more information, please contact kclay@wcl.american.edu. 
tool. The very ease of use that makes them appealing and powerful also requires a process of enormous simplification that is not necessarily transparent to the end user. ${ }^{5}$

In addition to recognizing the potential of empirical research to transform the questions we ask and the outputs we create, it is also time to begin having a serious discussion about what makes for effective and rigorous empirical research in the field of international law. Here, I would like to raise three issues: ethics, audience, and methodology.

The ethical questions follow directly from the transformative effect of empirical research on our outputs. Particularly if we are producing tools that are meant to be used directly by policymakers, we have an obligation to consider how those tools might be used or misused. We may decide that it is unethical to produce some tools at all, if the potential for misuse is too great. At a minimum, we must design our tools in such a way as to maximize the likelihood of careful use.

Relatedly, there are questions of audience. To ensure that empirical research is performed rigorously, we need to develop a community of international law scholars who can knowledgeably read and respond to empirical research and who can critique how it was performed. Even though many scholars will have no interest in conducting empirical research themselves, empirical researchers still need a critical mass of readers who are prepared to call us to account. Also, for our research to be effective, and especially for policymakers to understand the scope and limits of the tools we produce, we need to package and deliver our work so that it reaches an audience beyond the academic world. Seventy-five-page law review articles, dense with footnotes, are not an accessible vehicle; short papers, blogging, and meetings with policymakers are more likely conduits.

Finally, I have heard law described as a discipline without a methodology, and indeed, those of us who do empirical research typically borrow our methodologies from other disciplines and adapt them to our own purposes. As a consequence, we have not yet had a thorough intra-disciplinary discussion about the kinds of methods we consider appropriate for international law. What techniques are needed to generate reliable data and to appropriately correspond that data analytically to our theoretical concepts and policy goals? How should the methods borrowed from other disciplines be tweaked to address legal subjects? I do not expect that we will come to a single set of conclusions about these issues, but the discussion itself will help to produce some criteria, albeit contested ones, against which to measure the methods we use.

\section{Empirical Modalities: Lessons for the Future of INTERNATIONAL INVESTMENT}

\section{By Susan Franck*}

Empirical approaches add value to international investment law and aid in its evolution. Nevertheless, we must "fit the forum to the fuss." When transforming international law, we select proper methodologies for specific research questions and make international law empiricism part of a larger post-structuralist, pluralist legal dialogue. In connection with that, my remarks first place empirical research on international investment in a historical context. I then discuss where the research is today and offer an example of how empirical methods can be used to understand, reassess, and possibly transform international investment

${ }^{5}$ Id. at $20-21$.

" Of Washington and Lee University School of Law. 
law and related institutions. Finally, I consider the future of empirical research related to international investment.

\section{HISTORICAL FRAMEWORK}

The international political economy has always been a subject of academic interest. Yet it was largely the province of political scientists and economists focusing on investment flows. In 1967 the controversial article by Scaperlanda ${ }^{1}$ focused on differences in U.S. investment flows in Europe. Scaperlanda used econometric modeling to assess whether the creation of an EC common market was reliably linked to the relocation of U.S. foreign investment. Concluding that the data did not support a "reallocation theory," the research helped elucidate how a normative change in international law and institutions-namely the creation of the EEC-affected certain investment decisions.

Similarly, in the 1970s a case study of Columbia used qualitative interviews of 200 government officials to evaluate a new screening process for approving foreign investment and the link to investment flows. ${ }^{2}$ The study's aim was not to educate domestic government regulators or treaty negotiators; rather, it aided private parties' structuring of investment to secure entry into the domestic Columbian market.

These two examples, which were not randomly selected, nevertheless reflect a common theme. Namely, different research questions applied different empirical methods to illuminate issues related to international investment. Both studies focused on variables affecting investment flows; they were descriptive and proscriptive; they were designed to aid the ordering of private affairs. They did not address the normative choices about investment law and related institutions.

\section{The CurRent Landscape}

To put matters into perspective, during a December 2009 conversation, Professor Scaperlanda told me that empirical research in the 1960s and 1970s on international investment law was necessarily constrained given lack of access to data and technological limitations. Scaperlanda recalled that, to run a single regression, more than one room of computers, and a day of computing time, might be required. The transformation of technology and the increase in the availability of data create lower opportunity costs for conducting rigorous empirical research and begin to reflect the shifting interest in international investment empiricism. The rise of social science methodologies, non-state actors, and international institutions and technological innovation arguably creates a complex interaction that generates opportunities to reconsider how international law can and should operate; and this could involve using empirical methods to offer a different analytical framework for traditional units of analysis.

At present, empirical scholarship on international investment law has two core focuses. One aspect is more traditional. Like its historical predecessors, it focuses on which variables facilitate international investment and how to maximize that value through normative legal choices. What legal scholars add to the mix is encouraging the rigorous analysis of: (1) international agreements, like investment treaties; (2) domestic legal regimes related to investment; and (3) issues of scale related to those legal institutions. Lawyers have also encouraged political scientists and economists to enhance their methodological approaches

\footnotetext{
${ }^{1}$ Anthony Scaperlanda, The E.E.C. and U.S. Foreign Investment: Some Empirical Evidence, 77 EcoN. J. 22 (1967).

${ }^{2}$ Francois J. Lombard, Screening Foreign Direct Investment in LDCs: Empirical Findings of the Columbian Case (1967-1975), 9 J. INT'L Bus. STud. 66 (1978).
} 
by having a more accurate understanding of legal doctrine, the practical operation of law and the implications for creating meaningful variables with measurement validity. In other words, investment law scholars have added the "law" as a variable to the model of what affects foreign investment flows. To this end, I would point to the scholarship of Jason Yackee, Susan Rose-Ackerman, Andrew Guzman, and others. This research essentially considers the legal implications for "how do you get international investment?" or what I call investment facilitation research.

Another aspect of investment research focuses on "what happens once you have it?" which I call the investment implication research. This research explores the functionality of international investment law regimes in order to assess the system and its affiliated costs. This is the scholarship that, in the tradition of Marc Galanter's assessment of U.S. litigation myths, descriptively offers a critique of purported truisms about international investment. It is also scholarship that assesses those variables associated with outcome-and how the background of adjudicators of international investment law may (or may not) skew results. In the future it might grow even further-it might consider other areas of analysis beyond pure outcomes. It could grow to encompass larger process concerns (i.e., the role of third parties or mass claims), the implications for enforcement, good governance structures, domestic capacity-building, and the role of the rule of law. The ultimate goal of this scholarship is to inform normative policy choices and make recommendations for systemic improvements to investment law and associated international institutions.

\section{The Specific Example}

This research might be best illustrated through a concrete example. Some Latin American countries have critiqued the process of resolving international investment disputes as biased in favor of the developed world and that governments (except the United States) always lose. The implications of this are not insignificant. It has lead to: (1) the withdrawal of Bolivia and Ecuador from the International Centre for the Settlement of Investment Disputes (ICSID), a dispute resolution institution established by an international convention; (2) statements by ALBA $^{3}$ about the possible creation of an alternative international arbitration body; and (3) the withdrawal by states, such as Russia and Ecuador, from multilateral and bilateral international investment agreements. The phenomenon is not isolated; some South African officials have indicated that they will not sign international investment treaties that contain provisions to arbitrate before ICSID, particularly where they are primarily the capital-importing state.

So what does empirical analysis have to add to this debate? It permits the assessment of dispute resolution "myths" and the accuracy of conventional wisdom. It can also aid the considered construction and revision of international investment law.

Current data did not back up the claim that governments always lose. One set of pre-2007 data and measures suggested that governments won a bit more than fifty percent of the time. Meanwhile, the data did not suggest that it is catastrophic when governments do lose. Although this is likely to evolve as further data are coded and analyzed, the data indicated that amounts awarded by tribunals were in the order of US $\$ 10$ million. But that is not to say that there is no cause for concern. The data also showed that the average amounts claimed were in the order of US\$343 million, which is perhaps why-looking at that potential

\footnotetext{
${ }^{3}$ Alianza Bolivariana para los Pueblos de Nuestra América-Bolivia, Cuba, Dominicana, Ecuador, Honduras, Nicaragua, San Vicente y las Granadinas, Venezuela y Bolivia (Oct. 2, 2009), at http://www.hoy.com.ec/noticiasecuador/alba-evalua-creacion-de-tribunal-de-arbitraje-que-reemplace-al-ciadi-371086. html.
} 
exposure, plus associated costs of pursuing arbitration - that stakeholders complain about the rules of this high-stakes game. ${ }^{4}$

Overall, based upon on the preliminary models, the data did not find bias in the system, which seems to suggest that the system is not functioning unreasonably, but there is room for improvements at the margins or in specific subsets. Likewise, the data did not back up the assertion that the development background of the respondent state had a reliable statistical relationship with losing or amounts awarded. While replication and convergence of research is necessary (with more data and more nuanced models), this initial evidence contradicts the claim that the developing world is unfairly treated through the process of resolving investment disputes through arbitration. The initial evidence suggests that there is no reliable evidence demonstrating the arbitration system is biased; it also suggests that the "remedy" ALBA proposes to address the investment "problem" may not be properly tailored to address its underlying concerns.

This is a classic example of how "international law matters." Governments created legal frameworks on international investment. International bodies have begun to interpret the meaning of those structures; and those decisions are being implemented and enforced. Governments, investors, and civil society groups react to those processes and recommend adjustments to affect the future of the international investment law regime. Empirical methods, adapted to the specific research question and implemented properly, offer a vital—but not the onlytool to evaluate the present and create structures to promote the long-term sustainability of the international investment system.

\section{CONCLUSION}

The international investment system is evolving during a time of global economic crisis. I believe that there are several implications that will affect the future evolution of international investment law empiricism and the creation of international economic law and related institutions. First, we should expand research to address systemic evolution of the data. This may require expansion and consolidation of existing data sets to account for new experiences and look for points of historical demarcation. Second, we should be ready to entertain different types of research-whether quantitative, qualititative, or mixed methods. One size may not fit all; different units of analysis may require different approaches; and scholars should select the right methods to answer specific research questions. Third, we should ensure that data gathering and analysis are done rigorously in conformity with accepted social science practices. Without an explanation of methodological choices, it is difficult to assess the validity of the data and the inferences derived therefrom. Fourth, scholars should provide research in a format that encourages policymakers to use the data and inferences appropriately. Research is not about creating sound bites but providing nuanced information bound by context and respectful of methodological limitations. Finally, we should consider now how to build long-term longevity of investment law empiricism-whether by conducting metaanalysis, training empirical methodologists, or encouraging strategic collaboration across disciplines. In these ways we can support the proper growth, use, and understanding of empirical methodologies to gain the maximum benefits from international investment and the associated legal frameworks.

\footnotetext{
${ }^{4}$ Susan D. Franck, Development and Outcomes of Investment Treaty Arbitration, 50 HARv. INT'L L.J. 436 (2009).
} 